\title{
Achieving Environmental Sustainability (MDG7) in Nigeria: Progress so Far, Challenges and Prospects
}

\author{
Ademola Adeagbo \\ Economic Policy Research Department \\ Nigerian Institute of Social and Economic Research (NISER), Ibadan, Nigeria
}

\section{Doi:10.5901/ajis.2013.v2n6p47}

\begin{abstract}
The Millennium Development Goal Declaration was adopted by 147 Heads of States in September 2000. The member countries were expected to domesticate the global agenda based on the peculiar situation in each country. This was complied with by Nigeria. The country has taken lots of initiatives towards achieving all the eight goals with varying degrees of achievement. This paper focuses on Goal 7 which is "Ensuring environmental sustainability". It examines the progress made so far and reveals that the rate of the relevant targets has been slow, especially with respect to achieving environmental sustainability. Various challenges are identified in the course of achieving the goal. These include population explosion, high incidence of poverty, policy inconsistency, among others. The paper also observes some prospects towards achieving the goal. These include some aspects of the policy environment with respect to the relevant sectors, resource availability, among others. Based on all these, the way forward in the course of achieving the goal is discussed. This is discussed in line with the Pressure-State-Response (PRS) model.
\end{abstract}

Keywords; Environmental Sustainability; Millennium Development Goals; Policy Inconsistency; Pressure-State-Response

\section{Introduction}

In September 2000 a Millennium Declaration was adopted by 147 Heads of State. Inherent in this was a global agenda of eight Millennium Development Goals (MDGs), one of which is to ensure environmental sustainability, with time bound targets. The inclusion of ensuring environmental sustainability (MDG7) was informed by the recognition of the damage being done to the environment, as captured in the following quotations:

'By avarice and selfishness, and a groveling habit, from which none of us is free, of regarding the soil as property... the landscape is deformed.' (Henry David Thoreau (1817$1862)^{1}$

'Man has been endowed with reason, with the power to create, so that he can add to what he's been given. But up to now he hasn't been a creator, only a destroyer. Forests keep disappearing, rivers dry up, wild lifes become extinct, the climate's ruined and the land grows poorer and uglier every day. 'Anton Chekhov (1860 - 1904)

\footnotetext{
${ }^{1}$ Anton Chekhov (1860 - 1904), Russian playwright and short-story writer. Microsoft $®$ Encarta $® 2008$ 2 Ibid:
} 
In view of the above, the concern for ensuring environmental sustainability is not out of place. Though several measures had been devised in the past, the ineffectiveness of such measures and increasing threat to environmental sustainability led to the global concern which resulted in the Millennium Declaration. As noted by Tibaijuka (2005) the MDGs are people centered, time-bound and measurable. While the goals are universal, each country was expected to set targets considering local priority problems and resource capacity in recognition of individual county's peculiarities. Nigeria cannot but be part of these global campaign and desire to address all the social and economic crises that are devastating the well being of the people and which are targeted by the MDGs.

The situation in Nigeria, especially with respect to the problems addressed by MDG7 is parlous. For instance, UNDP observes that the country's natural resources, some of which constitute the country's national assets, are seriously threatened (www.ng.undp.org/ mdgsngprogress.shtml). The state of the components of the environment is as illustrated in Box 1. The Nigerian government is not oblivious of the magnitude of the problem and the need to address the challenges squarely. Thus, in line with global thinking on making life better by striving to attain the goals and targets of MDGs, Nigeria set in motion the machinery for achieving the MDGs by 2015.

A policy Brief by UNDP (www.ng.undp.org/mdgs/policy_brief.pdf) catalogues the various efforts of the government. As stated in the policy brief, two of the steps taken by the government relate to the adoption of MDG-based planning and the commissioning of an MDG Needs Assessment study with the broad objective of providing a solid foundation for policy, budgeting, planning and financing strategy on the MDG. The study was conducted and its findings provided inputs into the policy brief prepared by the UNDP. Further efforts made to address the various challenges facing the country and which are part of the constraints militating against attainment of the MDGs include:

- Economic reforms with the launch, in 2004, of the National Economic Empowerment and development Strategy (NEEDS) at the Federal level; the State Economic Empowerment and Development Strategy (SEEDS) at the State level and the Local Economic Empowerment and Development Strategy (LEEDS) at the local level;

- The envisioning of placing the country among the top 20 leading economies in the world by 2020 leading to the preparation of the Vision 20:2020 document in October 2009 and the preparation of the consequent preparation of the Fisrt National Implementation Plan for NV20:2020 (2010-2013);

- The Introduction of the 7-Poit Agenda, focusing on:

- Sustainable growth in the real sector of the economy;

- Improvement of infrastructure (power, energy and transportation);

- Agriculture and agro-industry development;

- Human capital development (education and health)

- Security, law and order (including electoral reform)

- Combating corruption; and

- Conflict resolution through promoting equitable and sustainable regional development (Niger-Delta development)

- Adoption of MDG-related development planning in 2006 to channel investments quicly for meeting the MDGs

- The establishment of the Virtual Poverty Fund (VPF) into which fortuitous gains from the debt relief are pooled and from which MDG activities are financed;

- Inauguration of the Presidential Committee on the Assessment and Monitoring of the MDGs in Nigeria; 
- Introduction of Public Expenditure in NEEDS (OPEN), for tagging and tracking MDG expenditures;

- Establishment of the Office of the Senior Special Assistant to the President on Millennium Development Goals (OSSA-MDGs).

Box 1: The State of the Nigerian Environment

Nigeria's natural resources, some of its most valuable national assets, are still seriously threatened. For example, between 2000 and 2010 the area of forest shrank by a third, from 14.4 per cent to 9.9 per cent of the land area.

Similarly, access to safe water and sanitation is a serious challenge for Nigeria. Little progress was made up to 2005 but improvements since then have brought the proportion of the population accessing safe water to 58.9 per cent and the proportion accessing improved sanitation to 51.6 per cent.

The major challenge lies in translating substantial public investments in water into effective access. This requires more involvement by communities to identify local needs, and better planning to deliver holistic and sustainable solutions. In sanitation, efforts are falling short of the target. Rural-urban migration will add to the pressure on sanitation infrastructure throughout the country. It is doubtful that town planning authorities have made adequate preparations for sustainable housing and sanitation.

There is an urgent need for managerial, technical and financial resources to deal with these challenges to be established at state and local government levels. Given the risks of over-exploitation of groundwater in the North and the influx of saline water in the South, innovative solutions are required across the country.

Source: (www.ng.undp.org/mdgsngprogress.shtml)

The foregoing is a pointer to the seriousness of the government about the intention to ensure that all the social, economic, physical and environmental challenges set to be addressed by introduction of MDGs are solved with a view to attaining the goals and targets by 2015.

Since the focus of this paper is MDG7, efforts are made to examine the goal and the targets set for the country, how the country has fared in achieving the targets, the prospects for achieving the goal and the targets as well as the challenges and the steps to take to ensure there is remarkable progress.

\section{Environmental Sustainability}

It is considered pertinent to examine what environmental sustainability entails. As noted by Harris (2000), the need to achieve environmental sustainability is rooted in the recognition of the fact that the benefits of development have been distributed unevenly and there have been major negative impacts of development on the environment and on the existing social structure. It is recognized 
that many traditional societies have been devastated by depletion of forests, disruption of water systems, and intensive fisheries while urban centers in many developing countries suffer from extreme pollution and inadequate transportation, water and sewer infrastructure. This negative trend is also captured by Margaret $\mathrm{Mead}^{3}$, as follows:

We are living beyond our means. As a people, we have developed a life-style that is draining the earth of its priceless and irreplaceable resources without regard for the future of our children and people all around the world.' Margaret Mead (1901 - 1978)

The fear is that if the trend continues, the achieved benefits of development may be eroded. There may also be a collapse of the ecosystem while the present and future development may be jeopardized. Out of this grievous concern, there was global effort at addressing the problem of conflicts between environment and development goals by formulating a definition of sustainable development which has to do with meeting the needs of the present without compromising the ability of future generations to meet their own needs.

As further elaborated by Harris (2000), there are three aspects of Sustainable Development economic, environmental and social. The bottom line is that a concept of sustainable development should be concerned with finding solutions to social inequities and environmental damage and at the same time ensuring a sound economic base. Thus, according to Harris, sustainable development approach recognizes that:

- The conservation of natural capital is essential for sustainable economic production and intergenerational equity;

- Again from the point of view of neo-classical economic theory, sustainability has to do with maximization of human welfare which includes food, clothing, housing, transportation, health and education services, etc.;

- From an ecological perspective, both population and total resource demand must be limited in scale, and the integrity of ecosystems and diversity of species must be maintained;

- With respect to social equity, the fulfillment of basic health and educational needs, and participatory democracy are crucial elements of development and are interrelated with environmental sustainability.

From the foregoing, it could be discerned that achieving environmental sustainability (MDG7) requires a holistic and multi - sectoral approach which must also recognize the need for wider participation in terms of policy formulation and design of projects and programmes as well as their implementation and monitoring.

\section{MDG7: Goal and Targets}

MDG7 is to ensure environmental sustainability and it is expected to be achieved by meeting three targets - targets 9,10 and 11 in the overall MDG framework. These targets respectively are: integrating the principles of sustainable development into country policies and programmes; reverse loss of environmental resources; and reduce by half the proportion of people without sustainable access to safe drinking water; and achieve significant improvement in the lives of at least 100 million slum dwellers, by 2020. Each of these three targets has a set of indicators for monitoring progress made towards achieving them. They are as indicated Table 1.

\footnotetext{
${ }^{3}$ Margaret Mead, U.S. anthropologist. Redbook, "The Energy Crisis-Why Our World Will Never Again Be the Same" Microsoft @ Encarta @ 2008
} 
Table 1: MDG7 - Targets and Indicators

\begin{tabular}{|ll|}
\hline \multicolumn{1}{|c|}{ Target } & Indicator \\
\hline $\begin{array}{l}\text { 9. Integrating the principles of } \\
\text { sustainable development into country } \\
\text { policies and programmes }\end{array}$ & $\begin{array}{l}\text {-proportion of land area covered by forest } \\
\text {-proportion of gas flared } \\
\text {-energy use (kg oil equivalent) per \$1GDP } \\
\text {-carbon dioxide emissions (per capita) }\end{array}$ \\
\hline $\begin{array}{l}\text { 10. Reduce by half the proportion of } \\
\text { people without sustainable access to safe } \\
\text { drinking water }\end{array}$ & $\begin{array}{l}\text {-proportion of total population with access to } \\
\text { safe drinking water (\%) }\end{array}$ \\
$\begin{array}{ll}\text {-proportion of total population with access to } \\
\text { basic sanitation (\%) }\end{array}$ \\
\hline $\begin{array}{l}\text { 11. Achieve significant improvement in } \\
\text { the lives of at least 100 million slum }\end{array}$ & $\begin{array}{l}\text {-proportion of people with access to secure } \\
\text { twenure (\%) }\end{array}$ \\
\hline
\end{tabular}

Source: Federal Republic of Nigeria (2007): Millennium Development Goals 2006 Report, The National Planning Commission, Abuja.

\section{The Progress so far}

The level of attainment of targets of MDG7 is as indicated in table 2 as contained in the country's 2010 MDG report (FRN, 2010). The table indicates worsening situation with respect to loss of environmental resources. For instance, the proportion of land area covered by forest which is targeted to be $15 \%$ by the year 2015 , dropped from $18.9 \%$ in 1990 to $14.4 \%$ in 2000 . Since then there is paucity of data to update the trend of progress made. However, there have been mounting cases of deforestation, oil spillage, erosion and desertification. All these aggravate loss of environmental resources and threaten attainment of the relevant target.

With respect to the target of halving the proportion of people without sustainable access to safe drinking water and basic sanitation, while the performance of sanitation indicator is a bit better than that of water, the fluctuation in the level of trend of progress of the two indicators is a source of concern. As at 1990, the proportion of population using an improved drinking water source was $54 \%$ which increased to $66.25 \%$ in 2003 and drastically dropped to $49.1 \%$ in 2007 but increased again to $58.9 \%$ in 2009 (figure 1). In essence, the country was able to improve access to improved drinking water source by 4.9 per cent between 1990 and 2009 (a period of 19 years) indicating an annual increase of $0.26 \%$, whereas in three years' time the country is expected to increase access to this source by $18.1 \%$ in order to meet the 2015 target of $77 \%$ indicating annual increase of about $6 \%$.

With respect to sanitation, the proportion of population with access to improved sanitation was $39 \%$ in 1990 . This increased steadily to $49.8 \%$ in 2003 , dropped to $33 \%$ between 2005 and 2006, increased to 53.8 per cent in 2008 and dropped to 51.6 per cent in 2009 (figure 2). The country was able to increase access to improved sanitation by $12.6 \%$ between 1990 and 2009 (a period of 19 years) indicating an annual increase of less than 1\%. In order to meet the target of $70 \%$ access by the year 2015 (a period of three years from now), access has to be increased by $18.4 \%$ indicating annual increase of about $6 \%$.

With respect to achieving significant improvement in the lives of at least 100 million slum dwellers, the country's 2010 MDG report does not contain level of progress as it does for other targets for MDG 7.

However, the report indicates that one of the country's greatest challenges is providing adequate housing for the growing population. It is further recognized that the country has an estimated deficit of about 16 million housing units, requiring the construction of about 2 million 
units annually to meet the shortfall. The implication is that achieving significant improvement in the lives of at least 100 million slum dwellers by 2015, which is two years from now, becomes difficult if not impossible.

Table 1: Progress in the level of attainment of MDG7- Ensure Environmental Sustainability

\begin{tabular}{|c|c|c|c|c|c|c|c|c|c|c|c|c|c|}
\hline Indicator & 1990 & 2000 & 2001 & 2002 & 2003 & 2004 & 2005 & 2006 & 2007 & 2008 & 2009 & 2010 & $\begin{array}{c}2015 \\
\text { Target }\end{array}$ \\
\hline \multicolumn{14}{|c|}{$\begin{array}{l}\text { Target 7.A- Integrate the principles of sustainable development into country policies and } \\
\text { programmes and reverse the loss of environmental resources }\end{array}$} \\
\hline $\begin{array}{l}\text { Proportion of } \\
\text { land area } \\
\text { covered by } \\
\text { forest }(\%)\end{array}$ & 18.9 & \begin{tabular}{|l|l}
14.4 \\
\end{tabular} & n.a & n.a & n.a & n.a & n.a & n.a & n.a & n.a & n.a & n.a & 15 \\
\hline \multicolumn{14}{|c|}{$\begin{array}{l}\text { Target 7.C-Halve, by } 2015 \text {, the proportion of people without sustainable access to safe drinking } \\
\text { water and basic sanitation }\end{array}$} \\
\hline \begin{tabular}{|l} 
Proportion of \\
population \\
using an \\
improved \\
drinking water \\
source $(\%)$ \\
\end{tabular} & 54 & 54 & 62.11 & 64.21 & 66.25 & 57 & 60 & 50.9 & 49.1 & 55.8 & 58.9 & n.a & 77 \\
\hline \begin{tabular}{|c} 
Proportion of \\
population \\
using an \\
improved \\
sanitation
\end{tabular} & 39 & 42.9 & 42.9 & \begin{tabular}{|l|}
49.4 \\
\end{tabular} & 49.8 & 38 & 33 & 33 & 42.9 & 53.8 & 51.6 & n.a & 70 \\
\hline
\end{tabular}

Source: FRN (2010) Nigeria Millennium Development Goals Report 2010, Office of the Senior Special Assistant to the President on MDGs (OSSAP-MDG), Abuja

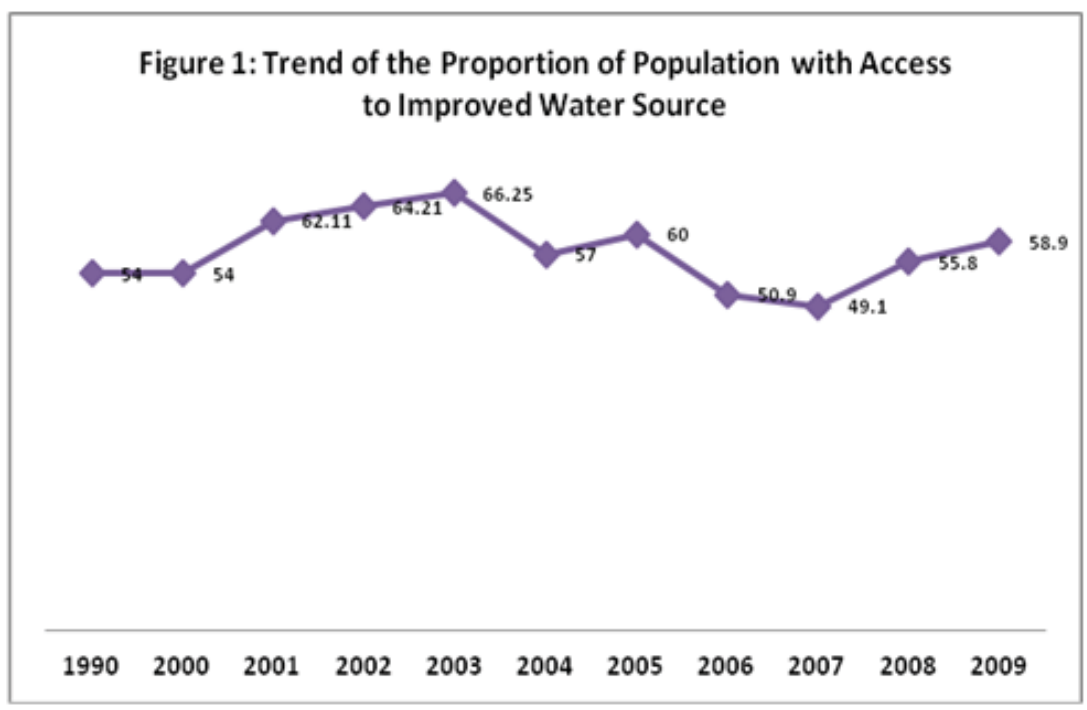




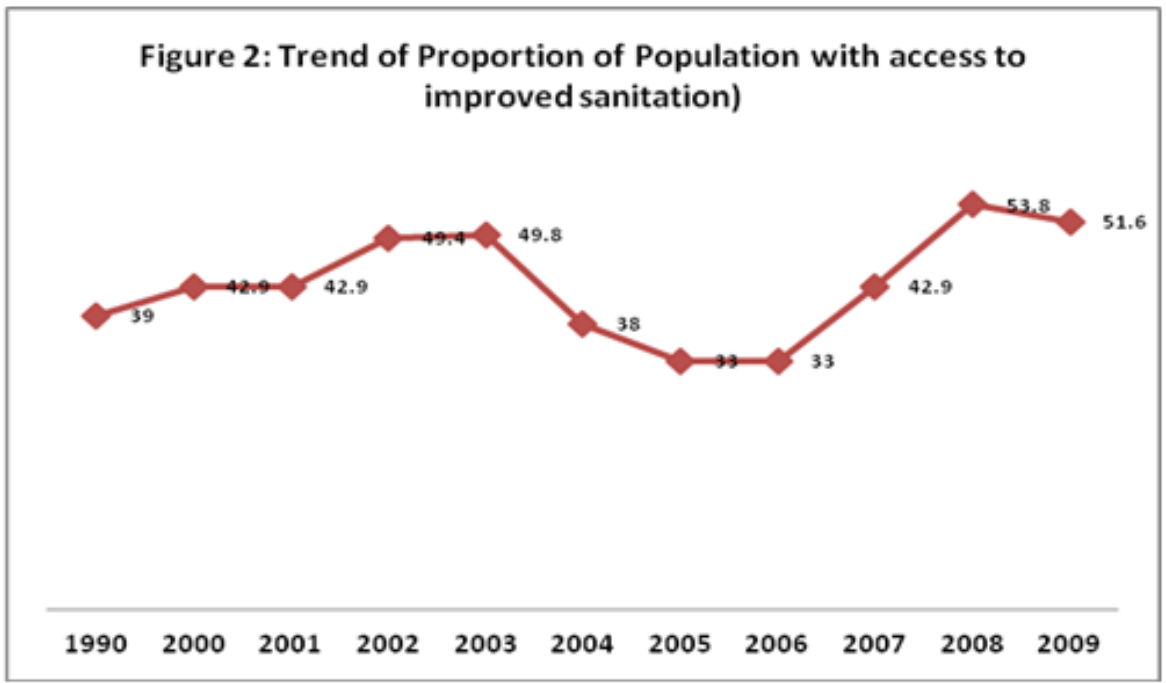

\section{Challenges Militating against Achievement of Environmental Sustainability}

Definitely there are challenges and limitations in the path towards achieving MDG7. Due to limited space some of them are highlighted as follows:

- Population Explosion: The country's population is exploding and there is no visible sign of any measure aimed at controlling the upsurge. There is a direct link between environmental resource exhaustion and population pressure. Increasing and uncontrolled population growth will render any well intended policies and programmes aimed at achieving MDG7 ineffective.

- High Poverty Incidence: People are getting worse off and the situation is being compounded by collapse of infrastructure. There is also a direct link between poverty and environmental resource depletion, thus with increasing impoverishment of people, achieving MDG7 could be a phantasm.

- Policy Inconsistency: There have been cases of policy inconsistency. With respect to economic policies, between 1986 and 2013, the country has experimented with:

- Structural Adjustment Program

- National Economic Empowerment and development Strategy (NEED)

- Vision 20:2020

- 7-Point Agenda

- Transformation Agenda

The implementation of these highlighted economic blueprints and strategies has not had significant impact on poverty reduction. With respect to Housing, the 1991 Housing Policy could not achieve its objectives leading to the setting up of a panel in 2001 to review and prepare a new Housing policy. The activities of the committee led to the preparation and printing, in 2006, of Housing Policy and Urban development Policy which were never approved by the Federal Executive Council. It was not until 2012 that a new Housing Policy was approved indicating that there was a policy vacuum in the sector between 2001 and 2012. Within the period, the Federal Ministry of Works and the Federal Ministry of Housing and Urban Development were merged and demerged. This development makes it difficult to address MDG7 target 11 which is 'Achieve significant improvement in the lives of at least 100 million slum dwellers'. 
With respect to the energy sector, while there is campaign against forest depletion, kerosene, a popular cooking fuel is made hard to get and very expensive with people resorting to using forest products as cooking fuel, thus negating the objective of the campaign against forest depletions. This again makes it difficult to address MGD7 target 9 (target 7A for Nigeria)which is Integrating the principles of sustainable development into country policies and programmes' with particular reference to the proportion of land covered by forest, energy used and carbon dioxide emission.

With respect to water, the Federal Ministry of Water Resources (FMWR) was merged with the Federal Ministry of Agriculture (FMA) with the new nomenclature as Federal Ministry of Agriculture and Water Resources. In 1979 the two Ministries were separated and the FMWR stood on its own. However, in 1984, it was again merged with the Federal Ministry of Agriculture and Rural Development, only for the two Ministries to be separated again in 1989. The Ministry was later merged with the Ministry of Agriculture and it was part of this Ministry until April 2010 when the two Ministries were again separated. This inconsistency, no doubt, is part of the constraints against addressing squarely MDG7 target 10 (target 7C for Nigeria).

- Cross-cutting roles and weak coordination: There are cases where a particular target cuts across two or more ministries. An example is that of the Ministry of Agriculture and Rural Development and the Ministry of Environment when target 9 (target 7a for Nigeria) comes to mind. Another is that of the Ministries of Health, Water resources and Environment for target 10 (target $7 \mathrm{C}$ for Nigeria). With respect to target 11 there are the Ministry of Housing and Urban Development, the Urban Development Bank, the Nigerian Building and Road Research Institute. Individual efforts of these ministries and agencies are poorly coordinated.

- The 'Negative' Federal Might: MDG7 like all other goals is about people. It is about the grassroots, it is more of a local concern which should, of course, be initiated at the national level. However all efforts and activities aimed at achieving MDG7 and other goals are more prominently domiciled at the federal level. There is little commitment at the state and local government levels which should be more involved in these activities. The situation, however, is improving at the State level with the introduction of the Conditional Grant Scheme (CGS) which requires beneficiary states must contribute 50 per cent of the total cost of MDG projects for a particular year.

- Low level of awareness at the grassroots level: Level of awareness of MDG7 is low among the local populace. The strength of the campaign for better environmental management practice cannot be compared with that of HIV/AIDS (under MDG6) and Children Immunization (under MDG4) thus downplaying the importance of MDG7. The low level of awareness has restricted the participation of all in the drive towards achieving the goal.

\section{Prospects}

In spite of the challenges enumerated above, there are prospects for meeting the MDGs and particularly MDG7. These are discussed as follows.

\subsection{Policy Environment}

With respect to availability of policy documents and guidelines, the situation is impressive. For instance, in the area of environment, there is the National Environmental Sanitation Policy, there is the National Environmental Standards Regulatory and Enforcement Agency (NESREA), and there are Policy Guidelines on Solid Waste Management, among others. What is required is full implementation of the provisions of these policy documents and guidelines and full empowerment 
of the various MDAs and particularly NESREA. With all this, the problem of forest depletion and poor sanitation could be effectively addressed.

With respect to the Housing sector, now there are approved National Housing Policy and the National Housing Urban Development Policy, though yet to be made public. Furthermore, the Federal Ministry of Lands, Housing and Urban Development, the Federal Housing Authority and the Federal Mortgage Bank of Nigeria (FMBN) are making efforts to increase the housing stock. Examples include: the Mass Housing Initiatives, of the Federal Ministry in collaboration with the State governments and the Federal Capital Territory; the Public-Private Partnership Scheme, an initiative of the Federal Housing Authority; the partnership between the FMBN and the Urban Shelter Limited; among others. There are also the various efforts of the State governments in the area of urban renewal. These are efforts that could transform the housing sector, enhance housing provision and improve the quality of housing in slum areas. What is required again is targeting the real poor who are mainly slum inhabitants.

\subsection{Resource Availability}

The country is blessed with abundant resources. With respect to forestation, the land is enormous and rich in nutrients while there are various forest species to be planted. There is a full-fledged Forest Research Institute of Nigeria (FRIN) which has conducted various researches on forest production, the findings of which could be useful. What is required is the political will to invest in afforestation schemes.

With respect to water, Nigeria has a total water resource estimate of 267.3 billion cubic meters. It has surface water resource estimate of 26.7 billion cubic meters and ground water resources estimate of 51.9 billion cubic meters (FMWR (undated) Water Resources information profile). The water Supply Master Plan prepared in 1995 puts water requirement for the country by 2015 at 16.9 billion cubic meters with irrigation requiring 13.5 billion cubic meters and water supply requiring 3.4 billion cubic meters. This means the country has more than enough water resources to meet the needs of the population if well managed. In 1997, the Federal government through the FMWR commenced the process of reforming the Water resources sector in order to establish effective, efficient, functional and implementable policy, legislation, institutional arrangements and development strategies for Integrated Water Resources Management (IWRM). This is expected to enable the water resources to be developed, utilized and protected to the benefit of all in order to support economic growth, achievement of development goals, equity and the eradication of poverty. What is required is to curb corruption in the implementation of various projects and ensure fairness and equity in the location of water projects.

With respect to sanitation, there are various Development Partners and International NGOs assisting the country in improving the state of sanitation, especially in the rural areas where the proble of poor access to sanitation is endemic. Some of these are the WaterAid Nigeria and the United Nations I nternational Children Fund (UNICEF). There have been developed various Demanddriven sanitation approaches, one of which is the Community Led Total Sanitation (CLTS) which was introduced in 2007 and which as at November 2010 was being implemented in 30 States of the Federation including the FCT. What is required is increased commitment on the part of the State and Local governments.

With respect to the housing sector, in recent times, the private sector appears to be more active in housing and urban development activities. Through their association, the Real Estate Developers' Association (REDAN), which was established in 2001, the private sector has been 


\subsection{The Conditional Grant Scheme (CGS) Channel}

Before the CGS was introduced, the Federal government adopted the idea of channeling the Debt Relief Gains (DRG) solely through the Federal Ministries in 2006. However, the strategy exposed the challenges of delivering services from the federal level. The approach resulted in the exclusion of participating communities in the implementation process. The approach also assumed that the beneficiaries lacked the capacity, knowledge, and expertise to participate in the design and implementation process.

The CGS channel was put in place by the Federal government in order to improve the capacity of sub-national governments to deliver services as well as better coordinate MDG-related programmes across the three tiers of government. The role of the CGS is to channel funds, technical assistance, and best practice from the Federal Government to sub-national governments. Among the objectives is to reduce fiscal constraints that the States and Local Governments face, whilst improving their capacity and demand for effective service delivery.

\subsubsection{Objectives of the CGS}

As stated in the CGS document, the origins of the CGS were rooted in the desire for a more inclusive and effective approach to public investment and service delivery. The specific objectives include:

- Investing in MDGs at the State and local Government Level to ensure ownership and sustainability

- Empowering State and local Government to carry out their constitutional responsibilities

- Promoting improvements in public service delivery

- Encouraging improvements in public expenditure management

- Strengthening the partnership between the three tiers of government for national planning

- Involving communities in local development and generating feedback on performance.

The water sector is benefiting immensely from the CGS approach. This cuts across all the States of the Federation.

\section{The Way Forward}

In an attempt to suggest measures for strengthening efforts at achieving MDG7 it is considered imperative to illustrate how society, through development activities and use of natural resources, exerts pressures on the environment and how information about changes to the state of the environment as well as associated environmental pressures may be conveyed to society, which may then respond individually or collectively with policy, programme, stewardship, or behavioural measures, through the OECD's Pressure-State-Response (PSR) Model(UNDP, 2005) (Fig. 1).

The PSR model indicates three broad components- Pressure from human activities which could be direct or indirect, the State of the environment and natural resources affected by Direct and Indirect pressures through pollution, waste generation and resource use arising from human activities, and Response from economic agents such as administrators, households, enterprises, Sub-national (State and Local) and International community) based on information received on the state of the environment and natural resources. 
Figure 1: The Pressure - State - Response (PSR) Model

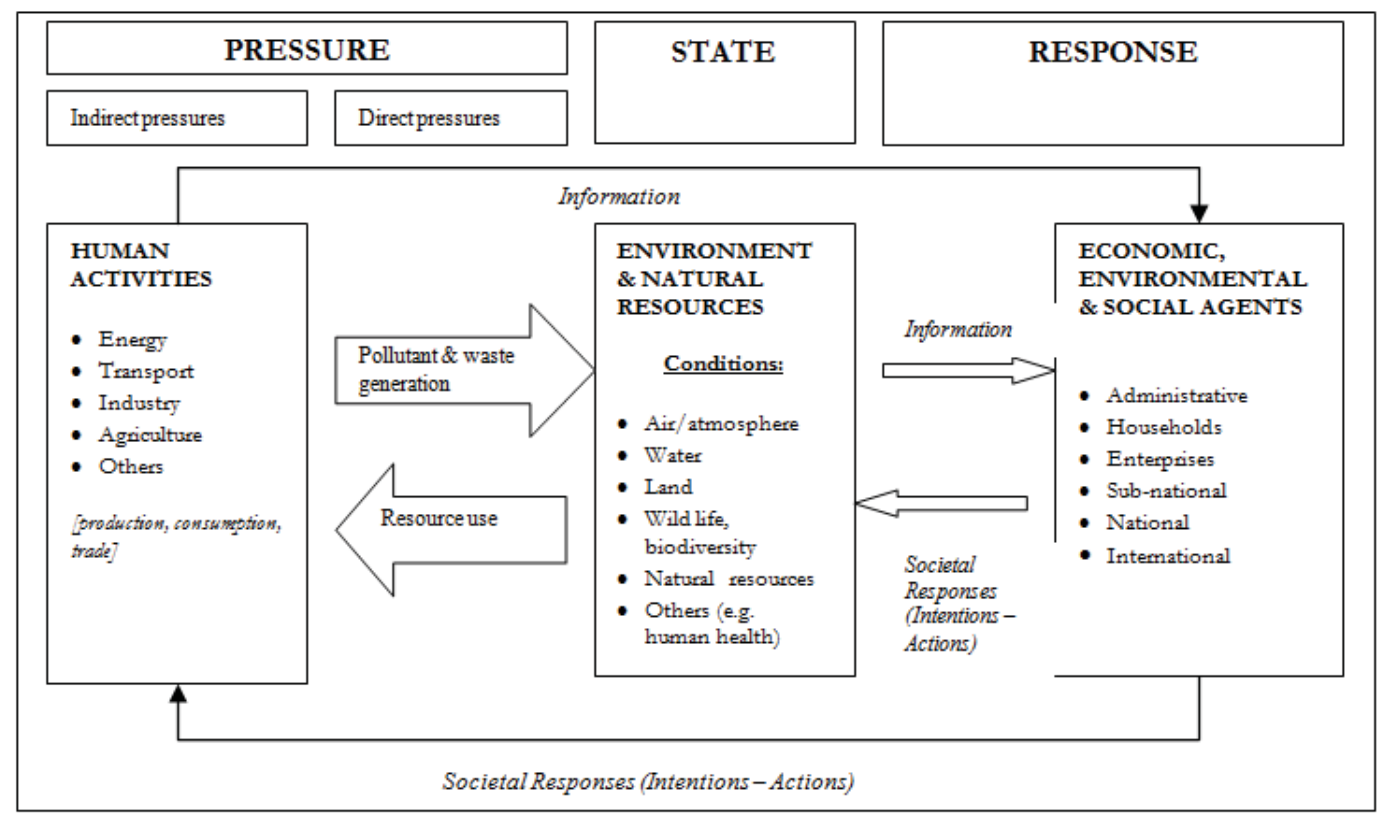

Source: OECD. 2001. Environmental Indicators: Towards Sustainable Development p.134 quoted in UNDP (2005) Monitoring Country Progress towards MDG7: Ensuring Environmental Sustainability, Practice Note, UNDP, March, 2005 p.12.

What can be gleaned from this model is that efforts aimed at addressing MDG7 should not be superficial. With respect to forest depletion, gas flaring, energy use, carbon dioxide emission (Target 9), water utilization and management, sanitary practices (Target 10 ), housing need and production (target 11), the following should be noted:

- A framework should be put in place that will enhance understanding, monitoring and controlling the operation of all human activities exerting pressures (direct and indirect) on the environment and natural resources;

- There should be a framework for identifying the type of pressures being exerted, the process of exertion, the process through which environmental resources are being utilized and changes in all these over time.

- There is need for putting in place strong machinery for observing and monitoring changes in the condition of the state of the environment and natural resources in general and in particular the relevant components of targets 9 to 11 .

- There is need for a powerful data coordinating mechanism which should ensure comprehensive processing and managing of data collected from different agencies dealing with monitoring of changes in the state of the environment. The National Bureau of Statistics (NBS) should be saddled with this responsibility.

- Existing fora for information dissemination such as ministerial briefing, publications by NBS should be strengthened and made accessible to all economic environment and social agents as indicated in figure 1. 
- The different roles expected of the various agents should be recognised and facilitation made for each of these agents to be able to play these roles. This is about the need to decentralise MDG7 activities and ascribe roles to different agents up to the household level. This calls for massive awareness and enlightenment campaigns, especially for nongovernmental agents.

- With respect to some of the identified challenges there should be aggressive drive towards effective population control, poverty alleviation, infrastructural development, access to affordable energy, among others.

- Since the MDGs are expected to be part of national policies, MDG7 should be incorporated into relevant policy initiatives.

\section{Conclusion}

The foregoing is an overview of the importance of MDG7, the progress made so far and the prospects for meeting the goal and the targets and the challenges in the way. Though the time bound for the attainment of the MDGs is just seven years away, all hope is not lost if we are able to right the wrongs in the relevant policy formulation and implementation processes as well as in the areas of project and programme implementation. It must be stressed that we cannot afford to toy with the environment, especially going by the following quotation:

'The environment is man's first right. Without a safe environment, man cannot exist to claim other rights, be they political, social, or economic.' Ken Saro-Wiwa (1941 - 1995)

\section{References}

Abdu Ja'afaruBambale (2011) National Economic Empowerment Development Strategy and Poverty Reduction in Nigeria: A critique, Economic and Financial Review I (I): 15-24, March, 2011, www.efr. businessjournalz.org

Adogamhe, P. (2007). The Nigerian National Economic Empowerment and Development Strategy (NEEDS): A critical assessment. A paper delivered at the 48th annual convention of international Studies Association, February 28th - March 3rd, 2007. Chicago, IL, USA.

Anton Chekhov (1860 - 1904), Russian playwright and short-story writer. Microsoft $₫$ Encarta $₫ 2008$.

Commission of the European Union (2006) Nigeria; Support to the federal Ministry of water Resources, Water Resources Management and Policy, lot no 2 COWI A/S by Atkins International, J une 2006.

Engr. M.A.K. Abubakar (undated) Evolution of Nigeria's water sector: Driving Forces and Constraints- A Nigerian Perspective, paper presented by the Director of Water Supply and Quality Control, FMWR, Abuja

Engr. M.A.K. Abubakar,( 2003), Water Supply and sanitation Sector Reform I nitiatives in Nigeria, Water Supply and Quality Control, FMWR, Abuja, sept

Federal Republic of Nigeria (2007): Millennium Development Goals 2006 Report, The National Planning Commission, Abuja

FRN (2009) Nigeria Vision 20:2020, Economic Transformation Blueprint, October 2009, National Planning Commission, Abuja

FMWR (undated) NIGERIA: Water Resources Information Profile; Water for People, water for Life (Presidential Water Initiative), Abuja

FMWR (undated) NIGERIA: Water Resources Information Profile; Water for People, water for Life (Presidential Water I nitiative), Abuja

FRN (2000) Water Supply and Sanitation Interim Strategy Note, November 2000

Harris J.M. (2000) Basic Principles of Sustainable development, Global Development and Environment Institute Working Paper, Global Development and Environment Institute Working Paper, Tufts University Medford MA 012155, USA http://asw.tufts.edu/gdae 
Henry David Thoreau, U.S. writer. Walden, or, Life in the Woods, "The Bean Field" Microsoft ${ }^{\circledR}$ Encarta (B) 2008.

Ken Saro-Wiwa, Nigerian writer and political and human rights activist: Message sent from prison upon winning the 1995 Goldman Environmental prize for campaigning against oil companies' environmental destruction in his native Ogoniland. Microsoft ${ }^{\circledR}$ Encarta ${ }^{\circledR} 2008$.

Margaret Mead, U.S. anthropologist. Redbook, "The Energy Crisis-Why Our World Will Never Again Be the Same" (Microsoft $®$ Encarta $® 2008)$

May 10, 2010 http://web.ng.undp.org/documents/NHDR2009/NHDR_SUMMARY_2008-2009.pdf

Onjefu Adoga (2006) Nigerian Water Policy and Law: A Need for Glōbal Compliance (martindale.com)

Peter Cookey (undated) Scaling up Water Sector Reform: Strategy for Sustainable Water Resources Management for Industrial and Domestic Purposes, Earth Conference on Water and Sanitation (The Nigerian Water and Sanitation Forum)

Peter Cookey (undated) Scaling up Water Sector Reform: Strategy for Sustainable Water Resources Management for Industrial and Domestic Purposes, Earth Conference on Water and Sanitation (The Nigerian Water and Sanitation Forum)

Tibaijuka Anna (2005) 'A Message from the Executive Director' The MDGs and the City, Habitat Debate, UN-HABITA, September 2005.

UNDP (2005) Monitoring Country Progress towards MDG7: Ensuring Environmental Sustainability, Practice Note, UNDP, March, 2005

(UNDP (2009), Human development Report Nigeria 2008-2009, United Nations Development Program,

UNDP (2009) Nigeria: The human development index - going beyond income. Human Development Report http//hdrstats.undp.org/en/countries/country_fact_sheets/cty_fs_NGA.html

UNDP Nigeria :: MDGs at a Glance Nigeria

www.ng.undp.org/mdgsngprogress.shtml 
